\title{
Overview of road performance on the tsunami evacuation road during the $\mathrm{n}$-COVID19 pandemic
}

\author{
Yossyafra ${ }^{1 *}$, Anyta Ramadhani ${ }^{1}$, Vina Gusman ${ }^{1}$, and Monica Herimarni ${ }^{1}$ \\ ${ }^{1}$ Civil Engineering Department, Faculty of Engineering, Andalas University, Padang, Indonesia, 25163
}

\begin{abstract}
The COVID-19 pandemic has changed the world in various sectors and human activities. Limiting human activity and mobility also has an impact on transportation and traffic. This study aims to calculate the capacity and performance of roads under normal pandemic conditions before PSBB (LargeScale Social Restrictions) in April 2020 and New Normal in July 2002, as well as predict traffic conditions if the Tsunami disaster hits the city during both periods. Tsunami Evacuation roads in Padang City were selected for analysis. The Indonesian Road Capacity Manual 1997 on urban roads is used as a reference for analyzing road performance indicators. The results showed that; road performance during the PSBB period was better than the New Normal period. The effect of volume and side traffic disturbance factors in the New Normal period makes a significant decrease in performance. Through prediction simulations, if a Tsunami occurs in the two study periods, the analyzed roads can relatively serve evacuation movements. However, the capacity needs to be increased for normal conditions.
\end{abstract}

\section{Introduction}

Since several earthquakes have occurred in Padang City, the roads have become overcrowded and full of refugee vehicles who want to evacuate to a safe place. At the time of the earthquake on September 30, 2009, in Padang, the community gained experience, that in the process of evacuating from a vulnerable area (beach) to an area that is estimated to be safe from the threat of a Tsunami, there has been a long traffic jam in each evacuation road section that in the city of Padang [1]. This can result in a hazard to the community, due to the congested and congested road conditions during the evacuation. The slow evacuation time due to vehicle density requires attention from the government to review the feasibility of the existing Tsunami Evacuation Road (TER), so that it still requires a short time and there are no barrier points (congestion) during evacuation and by the standards of an evacuation route.

Padang was chosen as the location of this research because it is the city with the largest population and the highest population density along the west coast of the island of Sumatra. Padang is also one of the cities at very high risk of the current Tsunami disaster in Indonesia. Then in a decade since 2009, Padang has succeeded in building several TERs, where the TERs built to have a large width, or are seeking to have a large service capacity.

However, over time, with the decrease in the intensity of earthquakes that have the potential for a Tsunami, it seems as if the Government and Society have forgotten to maintain TER so that it has a large capacity. In addition, it is also necessary for the government to monitor the performance of TER under various conditions.

The n-COVID19 pandemic that has hit the whole world since last December 2019, also provided valuable experiences for the government and society. During this pandemic, various types of restrictions on community movement and prohibition of vehicle traffic have been imposed by the government. Various types of restrictions that have been issued by the government are intended to stop the spread of the pandemic virus in the community.

In terms of the functionality of TERs, as required, it is very necessary to know the capacity and performance of roads, in conditions before PSBB (Large-Scale Social Restrictions) and New Normal and simulate it if a Tsunami occurs during this pandemic. This article describes the road performance during evacuation in several TER locations using simulation methods.

\section{Literature Review}

\subsection{Tsunami Evacuation Road (TER)}

Evacuation is the movement of a person from a dangerous area such as a disaster hazard to a safer area. Evacuation is the act of moving, moving, and saving people from a place of danger to a safe place [2]. There are two types of evacuation, namely: (1) horizontal evacuation is evacuation that is carried out by directing refugees to areas that are outside the reach of the tsunami such as hills or highlands that are not reached by the tsunami, meanwhile (2) vertical evacuation is carried out by

\footnotetext{
*Corresponding author: yossyafra@eng.unand.ac.id
} 
refugees to a safe height in the form of a shelter building, where the building is estimated to still be in the location of the tsunami coverage area.

TER is one type of vertical evacuation, one of the goals of the TER development is to facilitate and provide opportunities to escape from the coastline as quickly as possible to an altitude area that is safe from the threat of Tsunami. If a tsunami threatens, it is attempted so that the TER can be traversed by a large number of vehicles, to escape to a high-altitude location. According to Budi Susilo [3], TER is an important aspect to visualize the evacuation strategy that has been developed in an area. A good TER is that it can provide a safe path and there are not many barrier points (congestion) when residents are evacuated to a safe place even if only to the final evacuation place. It is required that the TER must be able to transport the entire population to be evacuated in a short time to a sheltering area or a clinic, hospital. So, the TER condition must meet the requirements in terms of quality, road material, road width, and distance from threatened areas to safe areas when evacuation occurs. An atmosphere of panic would certainly tend to occur during the evacuation so that more TER is needed in an area that is threatened with disaster.

Sea Defense Consultant [4], states that the width of the evacuation road can be used in urban areas with minimum width requirements:

- Primary Arterial Road: minimum width 10m,

- Secondary Arterial Road: minimum width 8m,

- Secondary Collector Road: minimum width $8 \mathrm{~m}$,

- Secondary Local Road: minimum width 4m,

- Residential road: minimum width is $4 \mathrm{~m}$.

The requirements of the evacuation route [5], are:

- Safety, which means that it must be completely safe from objects that pose a danger to oneself during evacuation.

- Short distance, which will be used must be a distance that is possible from the place of residence to a safe place quickly.

- Feasibility, which is selected at the time of evacuation must be feasible so that it does not hinder the evacuation process.

In 2012, the Padang City Government has issued Regional Regulation No. 4 of 2012 concerning the 20102030 Padang City Spatial Planning (RTRW). The document has listed six-city zones (Figure 1) [6].

\subsection{Traffic Management Monitoring Stage}

The sequential stages are known in Traffic Management and Engineering activities on urban roads are Planning, Organizing, Actuating, Monitoring, and Controlling. Each of these stages is a very important and mutually influential activity, that if one of the previous stages in its implementation is not or is not done well, it will adversely affect the results of the next stage.

Monitoring stages in traffic management can be done by analyzing road performance under conditions of implementation of a policy. The policy issued can be in the form of engineering in the form of (1) technical activities on roads (such as changes from two-way roads to one-way roads, prohibitions with road signs and markings) that want to improve their performance or can be in the form of public policies that regulate the general movement of people in general. comprehensive, such as (2) a public policy of limiting entry and exit of an area (city, country, etc.) that is hit by a pandemic, because it is feared that the virus will spread to people and quickly become a pandemic due to the mobility of people's movements.

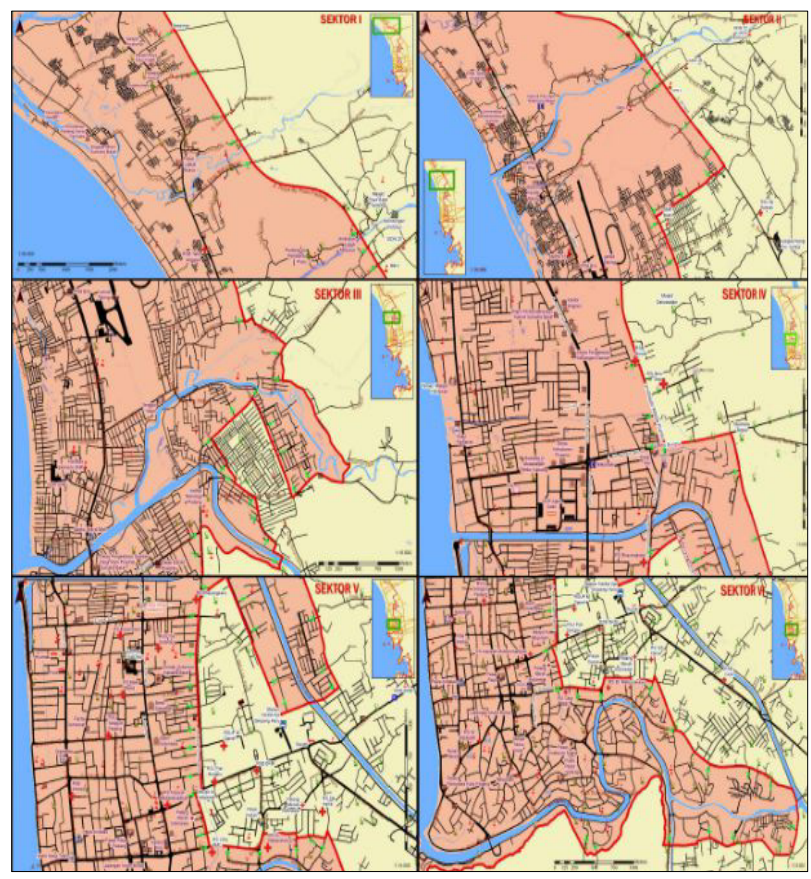

Fig. 1. Map of six horizontal evacuation route sectors in Padang

\subsection{COVID 19 Pandemic and Social Restriction}

Most cities in many countries around the world are currently facing the COVID-19 pandemic, which impacts all aspects of life, including political, economic, social, cultural, defense, security, public welfare, and mobility aspects [7]. COVID-19, as an infectious disease caused by the newly discovered SARS-CoV-2 virus, has become a pandemic. One of the impacts of this pandemic is the limited public mobility or community movement [8]. The effect also makes all forms of mobility, whether it's the mobility of people, goods, or services that were previously used to be done, are now completely limited due to the COVID-19 pandemic. A virologist in the United States notes that stopping travel is the best way to stop the virus from spreading [9]

Other countries have implemented various policies to contain the spread of COVID-19, including implementing lockdown policies, social distancing restrictions, restrictions on international flights, and the temporary suspension of the business sector [10].

The Indonesian government in dealing with the COVID-19 pandemic has also implemented restrictions on community mobility in stages,

- Large-Scale Social Restrictions (PSBB), where one of the things regulated is restrictions on private vehicles such as cars, a passenger restriction policy has been implemented so that each four-wheeled vehicle is only allowed half of the permitted vehicle capacity. 
- PSBB Transition, socio-economic activities in stages while still, applying certain limits [11].

This study aims to determine the capacity and performance of the TER section in pandemic conditions before PSBB and New Normal and to determine the performance of TER if a tsunami is simulated. The article also shows the influence of city government policies on changes in the level of community mobility that affect TER performance during the COVID-19 pandemic.

\section{Methodology}

This study went through several stages, which aimed to determine the effect of various government policies in restricting people's travel on TER performance in Padang. The stage was begun with conducting a literature study on TER and reviewing several public policies issued by the government in the transportation sector in reducing the impact of the pandemic. Then the next stage was the collection of primary data on several roads that have been designated as TER.

Data collection was carried out twice, the first was during a time when the pandemic had begun to spread rapidly, but there were no travel restrictions by the government. But at that time, individually or with family or one residential area, they had limited themselves not to travel from their place of residence. Traffic data was collected at three different TERs in Padang. Traffic volume data was collected by surveying for 12 hours from 06.30-18.30EIT continuously. Traffic volume data in both directions were recorded at an interval of 15 minutes based on vehicle classification. The results of recording the number of vehicles were converted into units of $\mathrm{pcu} /$ hour. Data on the adequacy of signs and markings on the evacuation route, carried out by direct inventory to the TER location and asked respondents' opinions on the adequacy of markings and signs along the TER.

There are some secondary data collected; data on the number of residents in urban villages along the TER (based on data published by the Central Statistics Agency of Padang) and data on vehicle ownership in Padang [12].

Then proceed with the data processing stage, which consists of data preparation, the process of preparing data for further analysis. The Indonesian Road Capacity Manual 1997 on urban roads was used as a reference for analyzing road performance indicators [13]. And the last stage was data analysis using a simulation approach. Through prediction simulations, if a Tsunami occurs in the two study periods, the analyzed performance of the TER was conducted. Then compared the volume of traffic in the two different conditions. The next step was to simulate the traffic volume prediction if there is a tsunami threat.

\section{Analysis and Results}

\subsection{Character and Capacity of TER}

In this study, three TERs were selected for investigation. Two of the TERs (Jalan Sawahan and Jalan Sisingamangaraja) are in the CBD and the other (Jalan
Pagang Raya) is about $5 \mathrm{~km}$ from the $\mathrm{CBD}$, which is also one of the important roads connecting the suburbs to the city center, which is also busy with traffic. The three TERs have met the requirements for evacuation roads (safe, short, feasible).

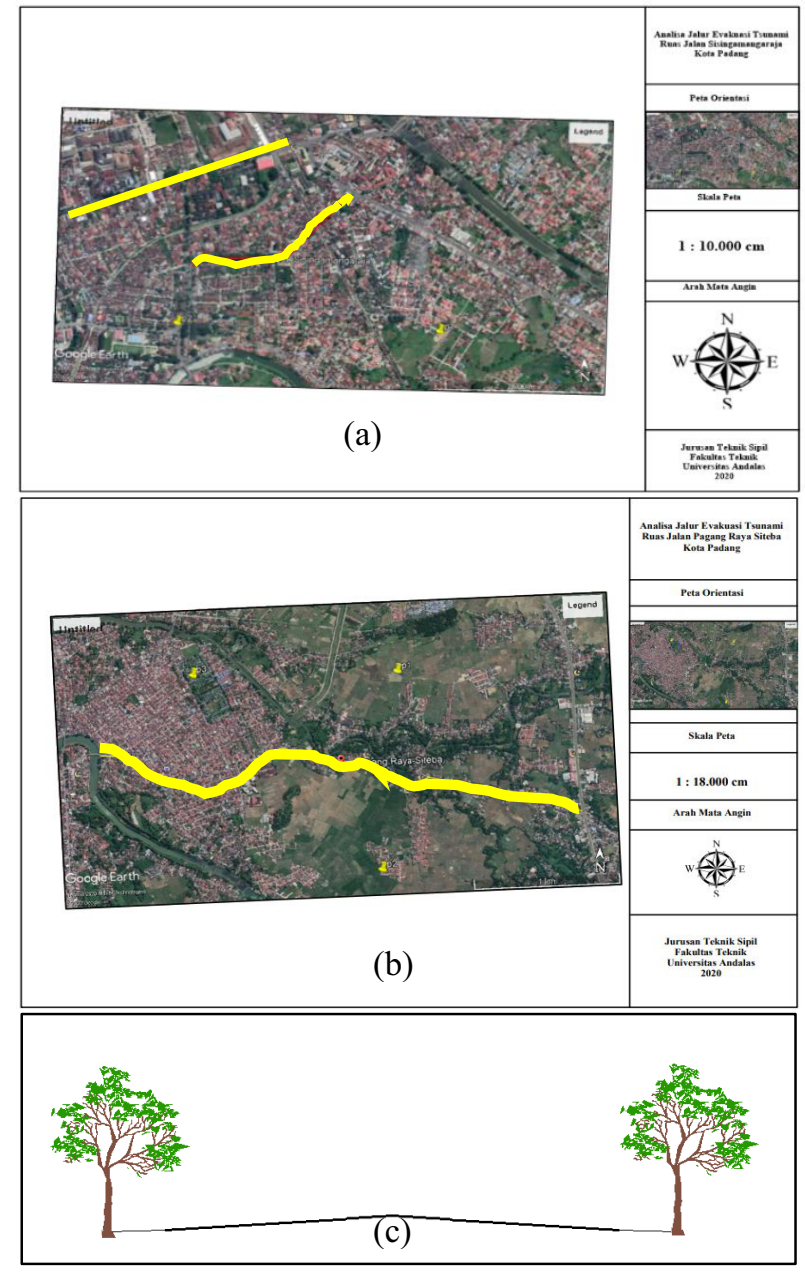

Fig. 2. (a) Location of Sawahan Road and Sisingamangaraja Road, (b) Location of Pagang Raya Road, (c) typical of the cross-section.

Table 1. The character of TER

\begin{tabular}{|l|c|c|c|}
\hline \multirow{2}{*}{ Characteristic } & \multicolumn{3}{|c|}{ Road (TER) } \\
\cline { 2 - 4 } & $\begin{array}{c}\text { Pagang } \\
\text { Raya } \\
\text { (TER1) }\end{array}$ & $\begin{array}{c}\text { Sisinga- } \\
\text { mangaraja } \\
\text { (TER2) }\end{array}$ & $\begin{array}{c}\text { Sawahan } \\
\text { (TER3) }\end{array}$ \\
\hline Type & $2 / 2$ UD & $2 / 2$ UD & $4 / 2$ UD \\
\hline Function & $\begin{array}{c}\text { secondary } \\
\text { collector }\end{array}$ & $\begin{array}{c}\text { secondary } \\
\text { collector }\end{array}$ & $\begin{array}{c}\text { secondary } \\
\text { collector }\end{array}$ \\
\hline Lane width (m) & $2 \times 3$ & $2 \times 3,5$ & $4 \times 3$ \\
\hline Co & 2900 & 2900 & 6000 \\
\hline$F_{\text {Cw }}$ & 0.87 & 1 & 0.91 \\
\hline$F_{\text {CSP }}$ & 0.97 & 1 & 1 \\
\hline$F_{\text {CSF }}$ & 0.94 & 0.90 & 0.84 \\
\hline$F_{C C S}$ & 0.94 & 0.94 & 0.94 \\
\hline C & 2162 & 2453 & 4311 \\
\hline
\end{tabular}

- UD : Un-divided,

- C : Capacity (pcu/hour)

- Co : Basic capacity (pcu/hour)

- $\mathrm{F}_{\mathrm{Cw}} \quad$ : Road width adjustment factor

- $\mathrm{F}_{\mathrm{CSP}} \quad$ : Directional separation adjustment factor

- $F_{C S F}$ : Side drag and road adjustment factor

- $\mathrm{F}_{\mathrm{CCS}}$ : City size adjustment factor 
Figure 2 shows (a) the location of Sawahan Road and Sisingamangaraja Road, and (b) the location of Jalan Pagang Raya, and (c) typical of the cross-section of each TER. And Table 1 shows the technical data and capacity of each TER.

\subsection{Traffic Volume of TER}

It has been explained in section 3, that to get road performance of TER, it was preceded by collecting traffic volume data during the PSBB and New Normal periods at each TER. The first traffic volume data were collected on Monday (April 20); Tuesday (April 21); and Wednesday (April 22) of 2020. That was a week before the government-imposed travel restrictions (PSBB) through regulations issued by the Governor of West Sumatra Province. The second collection of traffic data were collected on Monday (June 29); Wednesday (July 1); and Friday (July 3) of 2020. At that time the government had allowed the public to travel, but by complying with several health requirements (the New Normal period). Weather conditions at the time of the traffic volume survey were sunny days.

Figure 3 shows the traffic volume conditions on Jalan Pagang Raya as one of the TERs in the city of Padang, during the COVID-19 pandemic in 2020, with two types of periods, before PSBB and New Normal in 2020. In New Normal conditions (after PSBB) there is an increase in community mobility, which is indicated by an increase in the number of vehicles on the road. The difference in the average traffic volume ranges from 100 to $280 \mathrm{pcu} / \mathrm{hr}$.

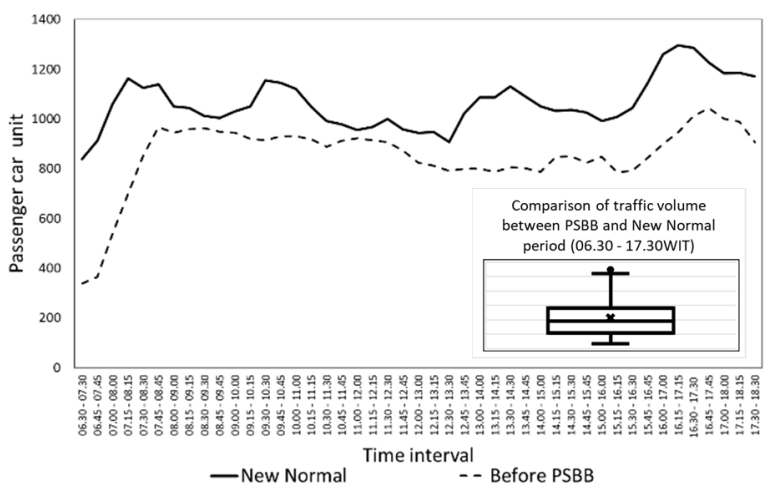

Fig. 3. Traffic volume of Pagang Raya Road in the period of before PSBB and New Normal.

Table 2. The Degree of Saturation of TER

\begin{tabular}{|c|c|c|c|}
\hline \multirow{2}{*}{ Period } & \multicolumn{3}{|c|}{ Degree of Saturation } \\
\cline { 2 - 4 } TER1 & \multicolumn{2}{|c|}{ TER2 } & TER3 \\
\hline Road Performance & 0.48 & 0,50 & 0,51 \\
\hline $\begin{array}{c}\text { before PSBB period } \\
\text { (April 2020) }\end{array}$ & 0.60 & 0,65 & 0,62 \\
\hline $\begin{array}{c}\text { New Normal periods } \\
\text { (June and July) }\end{array}$ & 0.73 & 0,71 & 1,10 \\
\hline Road Performance if Tsunami occur & 0,86 & 1,10 \\
\hline $\begin{array}{c}\text { before PSBB period } \\
\text { (April 2020) }\end{array}$ & $\begin{array}{l}\mid \\
\text { New Normal periods } \\
\text { (June and July) }\end{array}$ & 0.85 & 0,86 \\
\hline
\end{tabular}

Then the analysis has been continued to obtain the existing performance of each TER in the PSBB and New
Normal periods. Calculations have also been continued by adding traffic predictions in the event of a Tsunami.

Table 2 shows the degree of saturation of each TER. It can be seen that on TER3 (Sawahan Road) there is a very large increase in traffic volume in the event of a Tsunami. this is because Sawahan Road is the main road from the beach or CBD, where many activity centers are busy inhabited or visited by the community. For this reason, the government's attention is needed in formulating strategies and traffic management on the TER that are directed and measurable.

\subsection{Vehicle Mode selection during Tsunami Evacuation}

Direct interview surveys to individuals and families in communities living around the TER area were also conducted. This survey aims to obtain a choice of what vehicle mode will be used by individuals or families for evacuation if a Tsunami disaster occurs. In each area of TER, a questionnaire from 100 respondents has been collected, so that a collection of answers from 300 respondents has been obtained, which are presented in Table 3.

Table 3. The choice of the type of evacuation and the use of vehicles by the community if a Tsunami occurs

\begin{tabular}{|c|c|c|c|}
\hline \multirow{2}{*}{$\begin{array}{c}\text { Questions and } \\
\text { answers }\end{array}$} & \multicolumn{3}{|c|}{ Road (TER) } \\
\hline & $\begin{array}{l}\text { Pagang } \\
\text { Raya }\end{array}$ & $\begin{array}{c}\text { Sisinga- } \\
\text { mangaraja }\end{array}$ & Sawahan \\
\hline \multicolumn{4}{|c|}{ Evacuation action? } \\
\hline - Horizontal & $60 \%$ & $76 \%$ & $59 \%$ \\
\hline - Vertical & $20 \%$ & $13 \%$ & $30 \%$ \\
\hline - Stay at home & $18 \%$ & $11 \%$ & $11 \%$ \\
\hline \multicolumn{4}{|c|}{ If evacuating, what vehicle do you drive/ride? } \\
\hline - Car & $5 \%$ & $7 \%$ & $1 \%$ \\
\hline - By-cycle & $37 \%$ & $48 \%$ & $30 \%$ \\
\hline - walk & $20 \%$ & $21 \%$ & $28 \%$ \\
\hline
\end{tabular}

Table 3 shows that more than $60 \%$ of the population evacuated horizontally if a Tsunami occurred. And most of them use 2-wheeled motorized vehicles, while relatively few use 4-wheeled vehicles. It should also be noted that there are quite a several options for evacuating on foot. It is also the government's attention to providing facilities for pedestrians who are representative for evacuating the community if a Tsunami occurs.

\section{Conclusion}

The results of observation and analysis of three Tsunami evacuation roads (TER) in Padang Municipality indicate that:

- Under normal traffic conditions, the performance of the Tsunami evacuation road section is at Road Performance more than 0,50 , meaning that traffic flow conditions can still be said to be stable and moderate traffic density.

- Especially for Sawahan Road as TER, comprehensive traffic management and engineering is needed, so that the road can serve the community to evacuate if a Tsunami occurs 
- The government must conduct periodic reviews of all TER in the city of Padang, to ensure that it can become a TER that accommodates people who evacuate when a disaster occurs.

The author thanks the Faculty of Engineering, Universitas Andalas for providing research funding through the Publication of the Proceedings of the International Fund for Lecturers of the Department of Civil Engineering, with PNBP Funds in 2021 with contract No. 135/UN16.09.D/PL/2021.

\section{References}

1. Y Yossyafra, N. Fitri, N., R.P. Sidhi, Y. Yosritzal, D.I. Mazni, E3S Web of Conferences 156, 04008, (2020)

2. National Standardization Agency of Indonesia, SNI 7766:2012, Tsunami Evacuation Line (2012)

3. B. Susilo, S. Yarianto,"Analysis of Population Evacuations in Muria Nuclear Power Plant Accidents With Geographic Information SystemsApproach". Proceedings of the 13th National Seminar on Technology and Safety of Nuclear Power Plants and Nuclear Facilities. Jakarta, November 6, 2007. ISSN:0854 - 2910 (2007)

4. Sea Defense Consultant,"Tsunami Evacuation Planning Guidelines SDC-R-70022"(2007)
5. Kogami. "KnowledgeModule Facing Natural Disasters". Padang(2007)

6. Padang City Government, "Padang City Regional Regulation number 4 of 2012 on Spatial Plan of Padang City Region 2010 - 2030 Padang"(2012)

7. L. Hawryluck, "SARS Control and Psychological Effects of Quarantine", Toronto, Canadall, in Emerg Infect Dis, 11, 1206-1212, (2004)

8. N. K. Nissa, Y. Nugraha, C. F. Finola, A. Ernesto, J. I. Kanggrawan, A. L. Suherman, Smart Systems Journal 3, 02, 84 -94, eISSN:2622-8254, (2020)

9. J. Upton, "Pandemics Are the Dark Side of Global Mobility", Nautilus, no.84, (2020)

10. M. Nikola, E. Angela, H. Emily, "Impacts of COVID19 on Mobility", Preliminary Analysis of Reg. Trends Urban Mobility, Slocat, 3, (2020)

11. Y. R. Damuri, H. Aswicahyono, and D. A. W. Lestari,"Evaluation of Economic Activities and Intensity of COVID-19 Spread in New Normal Times: Review of Some Rapid Indicators" [Data Update June 29, 2020], CSIS, (2020).

12. Central Statistics Agency for the City of Padang, Padang in Figures, (2020)

13. Director-General of Highways, "Indonesia Road Capacity Manual", Ministry of Public Works, Jakarta, 563 (1997) 